\title{
Motivation for vocational training: significance to nurses in neonatal intensive care
}

\author{
Motivação para a formação profissional: significados para o enfermeiro de terapia intensiva neonatal \\ Motivación para la formación profesional: significados para el enfermero de terapia intensiva neonatal
}
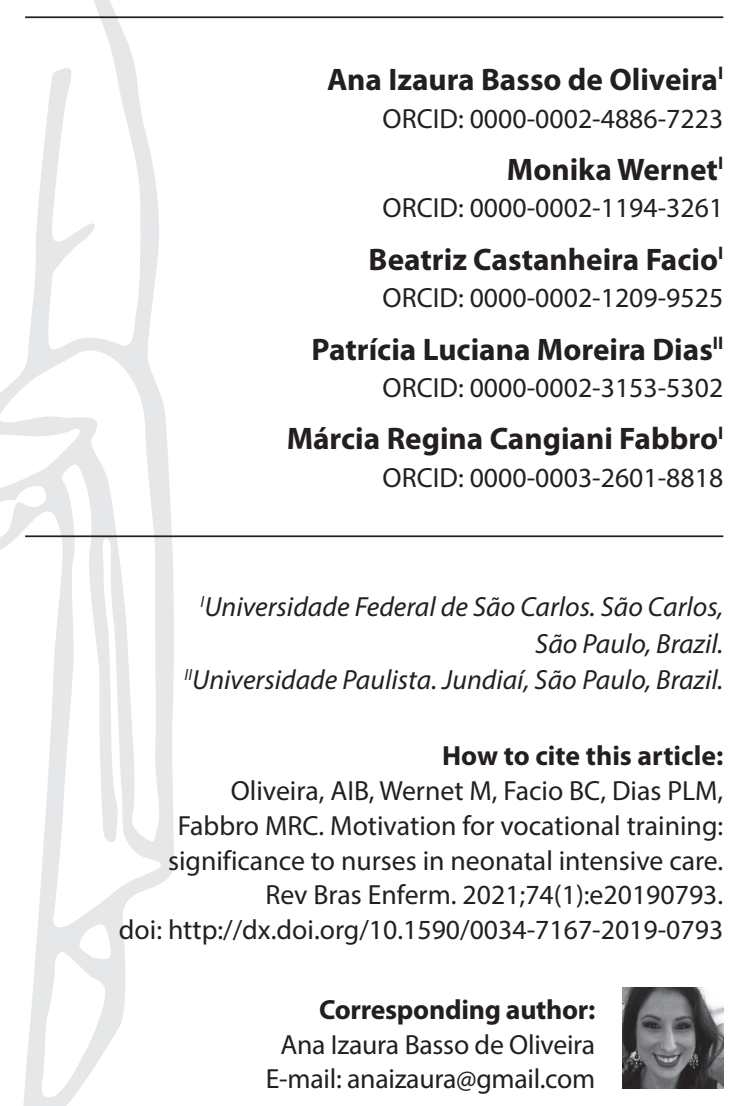

EDITOR IN CHIEF: Antonio José de Almeida Filho ASSOCIATE EDITOR: Fátima Helena Espírito Santo

Submission: $01-23-2020$

Approval: 08-28-2020

\begin{abstract}
Objectives: To analyze the motivation of neonatal intensive care nurses and the meanings attributed to the continuity of professional training. Methods: qualitative study, developed between August and December 2018, based on interviews with 16 nurses working in Neonatal Intensive Care in cities in seven Health Regions in the State of São Paulo. The theory of selfdetermination and narrative analysis supported this study. Results: the search for specialization and qualification of care is the plot, with the motivation for training initially based on the specialization and qualification of care. Over time, they revisit understandings carried out about care, making considerations about training, factors that influence motivation. Final Considerations: the motivation expressed by the nurse in the search for training is shown through movements marked by the limitations apprehended in practice on the care of the risk neonate and the acquisition of knowledge to act with quality in this specific health scenario. Descriptors: Nurses; Intensive Care Units, Neonatal; Education, Graduate; Motivation; Infant, Premature.
\end{abstract}

\section{RESUMO}

Objetivos: analisar a motivação de enfermeiros de Terapia Intensiva Neonatal e os significados atribuídos à continuidade da formação profissional. Métodos: estudo qualitativo, desenvolvido entre agosto e dezembro de 2018, a partir de entrevistas com 16 enfermeiras atuantes em Terapia Intensiva Neonatal em cidades de sete Regionais de Saúde do Estado de São Paulo. A teoria da autodeterminação e análise de narrativa sustentaram este estudo. Resultados: temse como enredo a busca por especialização e qualificação do cuidado, estando a motivação para formação, inicialmente, assentada na especialização e qualificação do cuidado. Com o tempo, elas revisitam entendimentos portados acerca do cuidado, fazendo ponderações sobre a formação, fatores que influenciam na motivação. Considerações Finais: a motivação expressa pelo enfermeiro na busca por formação mostra-se através de movimentos marcados pela limitação apreendida na prática sobre o cuidado ao neonato de risco e aquisição de conhecimento para atuação com qualidade nesse cenário específico de saúde.

Descritores: Enfermeiras e Enfermeiros; Unidades de Terapia Intensiva Neonatal; Educação de Pós-Graduação; Motivação; Recém-Nascido Prematuro.

\section{RESUMEN}

Objetivos: analizar la motivación de enfermeros de Terapia Intensiva Neonatal y los significados atribuidos al perfeccionamiento profesional. Métodos: estudio cualitativo, desarrollado entre agosto y diciembre de 2018, entrevistas con 16 enfermeras actuantes en Terapia Intensiva Neonatal en siete Regionales de Salud del Estado de São Paulo. La teoría de la autodeterminación y análisis de narrativa respaldaron este estudio. Resultados: tiene como enredo la búsqueda por el perfeccionamiento del cuidado, estando la motivación para formación, inicialmente, basada en la especialización y calificación del cuidado. Oportunamente, ellas revisan entendimientos portados acerca del cuidado, haciendo ponderaciones sobre la formación, factores que influencian en la motivación. Consideraciones Finales: la motivación expresa por el enfermero en la búsqueda por formación muestra por medio de movimientos marcados por la limitación aprendida en la práctica sobre el cuidado al neonato de riesgo y adquisición de conocimiento para actuación con calidad en ese escenario específico de salud. Descriptores: Enfermeras y Enfermeros; Unidades de Terapia Intensiva Neonatal; Educación de Posgrado; Motivación; Recién Nacido Prematuro. 


\section{INTRODUCTION}

Brazil is among the ten countries with the highest rates of prematurity per year, having twice as many premature births as the countries in Europe ${ }^{(1)}$. According to the World Health Organization (WHO), premature is a child born before completing 37 weeks of gestation. The cause of this event is multifactorial and is influenced by maternal conditions related to quality of life, health, social, economic and health conditions, and also, by conditions that lead to early induction of labor, congenital malformations, infections, genetic factors, among others ${ }^{(1-4)}$.

In view of this scenario and over time, with scientific and technological advances, quality of life and prevention of health problems has become fundamental to the development of good care practices, not only covering the reduction of mortality, but also ensuring transformations to the nursing process. Thus, the education of nurses must be a producer of meanings for caring, promoting discussions about the practice and integral needs of the new-born in critical condition, including prospecting for their future life environment ${ }^{(2,5)}$.

In view of these issues, addressing the motivation to train nurses in the Neonatal Intensive Care Unit is a necessary study to identify the needs for changes with a view to the potential for the development of teaching associated with practice. That said, motivation can be understood as the intensity and persistence of efforts directed by a person to achieve an aim, a goal or a dream, processed according to the importance given to those aspirations; thus, the motivation is dynamic and is maintained through individual and collective needs to organize human beings to the behavior that guarantees their success ${ }^{(2,6-7)}$.

Therefore, this work is based on the use of this theme in order to understand the mobilization of nurses to the training process during their work trajectory and to associate it with filling the existing gaps about care in Neonatal Intensive Care Units, seeking to improve the assistance to hospitalized neonates and reviewing constructive actions that help child development ${ }^{(2,8)}$.

\section{OBJECTIVES}

To analyze the motivation of neonatal intensive care nurses and the meanings attributed to the continuity of training.

\section{METHODS}

\section{Ethical aspects}

The study was approved by the Human Research Ethics Committee of the Universidade Federal de São Carlos (UFSCar) in line with Resolution No. 466, of December 12, 2012, of the National Health Council, meeting all ethical precepts.

\section{Theoretical-methodological framework}

The study was based on the theory of self-determination. This theory makes it possible to apprehend the meanings and mental processes involved in taking human action, whether personal or professional, and weighs the meanings carried and elements of the social context of nurses encompassed in motivational movements related to the search and involvement with training processes ${ }^{(2,9)}$. Narrative analysis as a method was applied to the collected data, due to its relevance in identifying the singularities of meanings in the nurses' stories about the search for training ${ }^{(2,10-11)}$.

\section{Study type}

Qualitative, descriptive-exploratory study with a qualitative approach of the analytical type. Such an option is given by the characteristics of the object of study, investigating and evaluating the facts through observation of social practices, perceptions and actions $s^{(2,9)}$.

\section{Methodological procedures}

To locate the participants, the "Snowball Sampling" technique was adopted, a form of non-probabilistic sample that, through references and key informants, seeks to signal individuals who can contribute to the research objective, aiming at building the chain of participants. The technique proves to be efficient in identifying specific populations that contribute to the development of understanding about the topic addressed ${ }^{(2,12)}$. The initial location came from consultation with members of the Health and Family research group at Universidade Federal de São Carlos.

\section{Study scenario}

The purpose of this study was with nurses who work in Neonatal Intensive Care Units (NICU) in cities that are part of the following Health Regions in the State of São Paulo: III - Araraquara; VI - Bauru; VII - Campinas; X - Piracicaba; XIII - Ribeirão Preto; XIV - São João da Boa Vista; XV - São José do Rio Preto — for being the areas with the greatest offer of scientific and technological training in the interior of the State of São Paulo, excluding the greater São Paulo and São Paulo city. The delimited region brings together $48.2 \%$ of the Intensive Care Units in the Southeast Region and $24 \%$ if compared to the country ${ }^{(2,13-14)}$.

\section{Data sources}

16 nurses working in neonatal intensive care were invited to participate in this study. The inclusion criteria in the study were: having a minimum experience of six months in the Neonatal Intensive Care Unit; and work in one of the cities that are part of the Regionals chosen and mentioned above. Exclusion criteria were: having less than six months' experience in neonatal intensive care; and/or work in other units not selected by the study ${ }^{(2)}$.

\section{Data collection and organization}

Data collection took place from August to December 2018, through semi-structured interviews, developed individually. They started with the following questions: "Have you ever sought any training to work in the NICU? What motivates you to do so? Tell me about this." Throughout the interviews, other questions were introduced to understand the motivation for continuing the training, its relationship with commitments regarding nursing care for the new-born in critical condition and family, in an 
articulated way to the narratives of the participants in order to expand the understanding of the topic exposed. The duration of the interviews was about one hour each. All were recorded on a digital audio device, both to facilitate narrative acquisition and to prevent the loss of significant data ${ }^{(2)}$.

The total number of study participants was 16 , using sample saturation as a criterion for finalizing the interviews, which must be verified from the treatment and analysis of collected data. Thus, this research adopted a procedural sequence when immersing in each record made, compiling the data analysis and gathering the identified themes, verifying the theoretical saturation of the categories that were recurring ${ }^{(2,15)}$.

In order to preserve the identity of the participants, the name was replaced by the letter $\mathrm{E}$ for a nurse, followed by an Arabic number assigned according to the order of the interviews (E1 to E16).

\section{Data analysis}

The data obtained from the interviews were analyzed using narrative analysis, a methodological strategy that focuses on the extraction, analysis and understanding of lived stories, based on their reconstruction based on significant components ${ }^{(2,14-15)}$. There was a continuous reading of the texts originating from the narratives contained in the interviews, to select the central element of the story and reflections aiming at the choice of terms and excerpts that allowed identifying structural content for the reconstruction of the story as well as inductive and interpretive analysis of the highlighted content. Thus, the construction of a narrative that allowed to list the "Search for specialization and qualification of care" while central plot ${ }^{(2)}$.

\section{RESULTS}

Sixteen nurses working in the NICU participated in the study, all female, belonging to the seven Regionals listed previously. The training time is between 1 and 25 years, with professional experience in neonatal care ranging from 1 to 18 years. Regarding the continuity of training, ten participants (62.5\%) underwent, at the time of the interviews, a lato sensu graduate course in Neonatal Intensive Care; one (6.25\%) had already completed a lato sensu graduate course in Hospital Infection Control; and one (6.25\%) was attending a stricto sensu post-graduation (doctorate) focused on paediatrics and neonatology. One quarter $(25 \%)$ respondents had specialized in NICU; and three quarters (18.75\%), completed the master's degree. All nurses reported having participated, at some point after graduation, in professional training courses with a short workload, less than 180 hours $^{(2)}$.

\section{Central plot: Search for specialization and qualification of care}

The insertion in the neonatology area occurred from different paths. Many of the participants had the desire to work in the area since graduation and started through direct entry to the NICU or through institutional relocation ${ }^{(2)}$.

[...] I started in a neonatal ICU, my first job... I always wanted this area... paediatrics, neonatology [...]. (E6)
Neonatal was an area of nursing that I never dreamed of working with, I always worked with adults and, when I was asked to go to the neonatal, I was terrified! But after a week I got a great love, it was love at first sight, working as a neonatal nurse was a professional achievement [...]. (E14)

The new reality demanded the expansion of knowledge and skills and, thus, preceding formal training, many revealed that, at first, they started both in individual and autonomous studies and in the search for neonatal nursing techniques with the NICU assistance team itself. However, these means were perceived as insufficient, and formal specialization emerged as a path to be followed. Thus, it is noted that the initial motivation is related to the work context and desire for improvement of knowledge ${ }^{(2)}$.

[...] I joined the neonatal in 2011, I stayed there a lot, I learned a lot from the girls, but in 2013 I went to graduate school. In fact, I looked for knowledge issues because it was very raw [...] I said "since I'm here, nothing better than specializing in this area", so I went looking for postgraduate studies. (E15)

What motivated me to do the post-graduate course was the need for work, because, in practice, we are identifying things that we don't know, so I saw that the courses would solve my doubts [...]. (E8)

In this direction of formation, the type of graduate chosen is lato sensu, as it is seen as more articulated to the desire to improve the quality of care, with possibilities of deepening knowledge of the neonatal area, a meaning that is superficially explored in undergraduate courses. Nevertheless, as a resource for updating the specialty and seeking professional challenges, they choose, mainly, the association between stricto sensu and academic career. Such choice still influences experiences lived during graduation, including together with professors who make up this stage $\mathrm{e}^{(2)}$.

[...] even for not having so much information in undergraduate courses, in a specific area, that there was a need to seek graduate studies [...]. (E4)

The master's degree was, on the other hand ... it was to improve my qualification to improve my professional life, as I already worked, it was to improve both the practice, which needs knowledge, and to have another option also in the future to pursue an academic career. (E13)

When I entered private school, I saw that it was not so bad, that it was a good school, but in my day there was not as much incentive in research as there is now [...] Unlike public school, you already enter and it will not be a simple nurse, they prepare you for various things, they prepare you for you to work at the clinic, in the hospital, for you to be a master's student, prepare you for anything, but that was not the vision I had, I had the vision that II was going to graduate, work at the hospital and ready. (E11)

[...] it depends on the look of the teacher that the professional had. I have teachers who mirror me to this day. Teachers who have this experience [of continuing education] convey this to us [...]. (E12)

To choose the course, they also considered the repercussions for their personal life and the modality in which it is offered, weighing 
the advantages and disadvantages of the classroom compared to those at a distance. In many cases, despite recognizing benefits of the face-to-face model, such as direct exchanges with the teacher, some nurses have launched themselves in the distance mode due to the greater ease in reconciling study and work ${ }^{(2)}$.

[...] I needed something that would give me a much larger subsidy, and the face-to-face specialization course contemplated me... even through the exchange of experiences, you apply it in your daily life... not that you don't trust in distance education, butwhen you have a contact with the teacher, you create a bond and you get a subsidy [...]. (E5)

I liked it, I like it, because, like this, it is in my available hours and I can go to my house to get more, to concentrate more than often on the face-to-face course, having hours when we are dispersed or very tired, comes after the shift [...]. (E8)

After entering specific courses in the area in which they work, they begin to take into account the contributions arising from this process and the meanings attributed to knowledge ${ }^{(2)}$.

[...] you study, you already work with that, you combine professional and scientific experience. The technical part with the theory, you broaden your view of what is right and wrong, what you think and really are. Others notice it, respect it more. (E4)

[...] I already have a greater notion, now I already live, so I am feeling this difference. I want to continue studying, maybe do other postgraduate studies. (E6)

Achieving the expectations of knowledge acquisition is indispensable for the projection of new formations. In this sense, nurses prospect that the lato sensu postgraduate courses should foster contact with updated and in-depth information, however many faced the opposite of what was desired and were disappointed ${ }^{(2)}$.

I thought it was missing [...]. As it was a postgraduate course, giving an introduction on the subject would be cool, but it was very warm, you already experience that moment, you want more... it is just for me to have the diploma, because these are things that I already do in my day to day. (E15)

Then I realized how much the postgraduate course I did was lagging in every way; it was a postgraduate course that I say I only had the diploma proving that I am an intensive care professional, but it was very bad, the workload was bad, the internship field was an NICU where we did nothing [...]. (E16)

A motivating point to further expand training, advancing beyond a postgraduate degree, is complementarity, which is why six participants reported an intention to carry out or have already carried out processes related to other training. There were those for whom the motivation for new tickets was associated with the desire for better living conditions, with influence on hours, rota and work remuneration ${ }^{(2)}$.

I went to obstetrics, I was always in love with this part of childbirth, but my greatest charm was the baby, and then I started doing post-graduate studies at the NICU precisely because of obstetrics; one graduate program complements the other, and we deal with the baby. (E16)
I intend to do another postgraduate course... occupational nursing. You work in a company, you have more quality of life. There is not much involvement because they are different areas. One will be the heart and the other the reason, for the financial part. (E2)

In this formative walk, as they signify themselves as having clinical knowledge and dominating procedures common to the NICU context, they return to reflections on the role and skills needed by nurses, with an appreciation of humanization. In this sense, they appreciate attributes such as empathy, responsibility, humility, commitments to harm, involvement, dedication and attention, but they experience scarcity of opportunities in this direction, and there are, still, those who do not believe that this is a subject that can be contemplated in training by it is a ported value ${ }^{(2)}$.

[...] In this discussion of humanization, in-service training is not an issue. We do not discuss humanization in continuing education training. This is not discussed. So is it really worth it? [...]. I think that some way could be rescued to have in these continued training the awareness of professionals within this unit. (E4)

[...] learn how to puncture, how to pass a tube, you learn all this, it's the time that will give you this ... now, you are a nurse who welcomes you ... that's me [...] / don't think that the formation of an institution forms this, I should have, but I think it is not something that happens, it does raise awareness [...]. (E12)

In addition, they emphasize that quality accreditation processes limit the scope of humanization, mainly due to the imposition of protocols and consequent prioritization of administrative tasks ${ }^{(2)}$.

Humanization, I believe so, from my own experience, often speaking is very beautiful, because it has a seal of quality. Nowadays, all institutions go for this quality seal that preaches humanization, however, with our routine, our daily professional life, stress, we often give more importance to the administrative part, this is demanded of us, and then we leave out this humanized part, which is to take care of the family member, the parents, with the other people who involve together with the care of the child. This is in fact not charged with quality. (E4)

Thus, from the path experienced at the beginning of work in the NICU, the search for specific training and projections for future professional life enters the environmental context supported by the hospital and the relationships that are established there. The knowledge acquired in clinical practice integrates the involvement with new courses, either by offering in the occupational scenario, or outside it. Institutional encouragement and support are determinants that integrate the motivation for this movement to happen ${ }^{(2)}$.

At the institution, we have a lot of difficulty, precisely because of the scale, the schedule, so it is more difficult, we must double the hourly load to take time off. I got to work every weekend so I could have a day; they put some obstacles yes, it is not very quiet no. (E13)

There is a lack of recycling, information and training courses in order to continue to value concepts within the sector. The lack of training is very great, especially in my sector, this is leaving something to be desired. We can even suggest, but we are at the mercy of force majeure. (E5) 
In the history of the search for knowledge, some nurses mention that the admiration and encouragement provided by the direct supervisor were highlighted and were essential factors of motivation, which also came from the fact of being involved in the unit's care discussions and deliberations ${ }^{(2)}$.

I never thought about the master's degree, but my supervisor motivated me a lot, I was always very close to her, and she was doing her PhD. I thought it was great because she is very intelligent, she knows things that I was amazed... I asked: "How do you know all this?" She said to me: "You have to study." Then I started thinking about it. (E15)

In contrast to the aspirations listed by the extensive relationship with direct management, not feeling supported and recognized as a professional generates limitations and dissatisfaction with the work and desire for changes in the environment ${ }^{(2)}$.

We have no return, I think what weighs a lot for people who work in nursing is not having this recognition, in any of the fields. We don't have recognition when we do a good job; not that it is not our obligation, it is our obligation to always do a good job, but a "congratulations", "thank you", makes all the difference for us and does even more for the team. This motivates to seek more, to want to know more. (E16)

In this unfolding, the lack of an institutional look at issues of the neonatal specialty makes the nurses in this study responsible for taking on the educational development of the NICU nursing team $^{(2)}$

We have a nucleus, but neonatology is seen as an animal with seven heads, nobody wants it and nobody does it. In order to have continuing education, we, the nurses there, who have to do it, are a minimum number of nurses, and we are very charged to do things that are not the nurse's job. We ended up putting out the fire and running after a burnt-out lamp, an insect that entered the unit and what belongs to us, we don't do it, we only managed to correct it after we did the wrong thing, but there is no continuing education. (E14)

Thus, the experiences involved with professional practice and continuing education actions are elements that feed back into the quality of care provided. In this sense, the nurse's motivation was explicitly brought up by one of the participants; she pointed out to be evidence of the "death of the professional", of the lack of interest in graduating, when one of the biggest signs is falling into the routine and mechanically carrying out instituted protocols. In contrast, it brings the motivation to expand knowledge as a condition for professional life ${ }^{(2)}$.

It takes a lot more work to give quality assistance than to give any assistance and say that it didn't. For you, you have limited yourself to that, your mechanical assistance is enough, the child is not starving, it is clean, so your job is good, you don't need to look for anything else for her. I think that when it dies within us, we lose the sense of work, then it is time to stop everything and change the area, because what moves our work is to study, seek, bring what is new to us your sector to better serve children. We see the result of such simple things, but why can't we improve on the rest, which is more complex and deserves much more of our attention? Honestly, there would be no elements, I would not be able to mould a full service, there, seeing from the outside, because the failures are coming from all sides and I do not see that we can cover the whole context. These are behaviors that, unfortunately, some of us take, but we cannot continue; we fight to the maximum, everyone does their best, most of the time we have a good outcome, but to say that we have full care, I don't see. (E16)

\section{DISCUSSION}

We seek, from nurses working in the NICU, to understand how they experience their professional practices and how they are involved in the training process, through their demands and the emerging needs of actions aimed at care ${ }^{(2)}$.

The analyzes revealed how broad the motivation for training is, at the beginning of the trajectory, broad and connected to the objective of achieving competencies to work in the specialty and provide good care, based on their understanding of it. It is the development of procedural skills that values the intensive care clinic and can be attributed to the environment and care model characteristic of the $\mathrm{NICU}$, which emerged with a focus on ensuring survival of premature new-borns (PTNB) or those with other conditions s $^{(2,16-17)}$.

Embedded in the technical characteristics of hospital units, there is the fragmentation of the human being as parts to be analyzed by health professionals. In this sense, super-specialization is sought in order to meet the needs of the body through varied knowledge regarding the best and most advanced technological resources ${ }^{(2,18)}$. In this way, lato sensu training is the desired option and receives broad institutional support ${ }^{(2)}$.

In this journey, scientific knowledge absorbs the value of building a unique, widespread and consensual reality, that is, it deals with the objectivity of practical knowledge as a universal producer of subsidies for clinical performance and enabling support and adaptation to the most diverse complexities arising from Neonatal Intensive $\operatorname{Care}^{(2,19-20)}$. Thus, the issues of education deserve to be highlighted, since they bring nurses closer to the autonomy of knowledge about the PTNB, basing their practical performance and serving as a guarantee for the effectiveness of nursing care ${ }^{(2)}$.

Through the interviews, it was possible to observe a consensus for the search for training, in which they are linked to the improvement of care conditions, although nurses attribute different meanings to the action. This fact reinforces the valorization of scientific knowledge about the performed practice. The cyclical value given to the educational process allows to gain mastery over a certain pattern or subject, a result that transforms the professional through autonomy, expanding critical reflection to argue and intervene in the way they work ${ }^{(2,21-22)}$.

Concomitantly with lato sensu training and associated with what the practice reveals, some participants develop criticism about nursing care in the NICU and about the demands on nurses. In this sense, they are uncomfortable with the misalignment in relation to humanization, paying attention to the practices of other professionals who make up the NICU team ${ }^{(2)}$.

The nurses mentioned here, who are sensitized to fight for humanization, revisit their own formative process and find a differential in ported moral values, questioning whether the courses that target this audience encompass this aspect. In addition, 
they are aware of the knowledge gaps to work in neonatology and recognize the scarcity of investments in the theme and in the awareness bets within the micropolitical scope of their own team, both in nursing and, in a more tenuous way, of the other professionals ${ }^{(2)}$.

In this context, studies show that nurses tend to deal with differences in personal moral values and values present within hospital organizations through forced assimilation to institutional impositions, which finds, in health education, a way to incite changes in the environment. These challenges cast criticism on institutional systems for, in many situations, failing to foster professional development ${ }^{(2,6,22)}$.

A few nurses mention having an intrinsic empowerment that maintains a self-regulation capable of not "killing" them as a professional (to paraphrase a participant); and others, for not experiencing an extrinsically motivator, withdraw into the training movement and "die" as autonomous and motivated professionals ${ }^{(2)}$.

In general, it is understood that work processes need frequent critical-participative reflections, seeking to contribute to overcome the difficulties encountered in reality. In the sphere of nursing, it is perceived that training must provide accumulation of professional knowledge, as well as being an innovative strategy for the service provided. It is projected, in the acquisition of knowledge, the practical application of new methods, procedures, conducts and attitudes, building a professional able to stimulate and propose changes in the work environments and be an essential element in the search for innovative and resolving solutions $s^{(2,5,23)}$.

In this context, it is possible to identify that one of the main challenges currently faced by the improvement and specialization courses that deal with this theme is to contextualize and tune the experiences encountered in the daily life of the professional with the offer of new knowledge that form socio-cultural and technical skills- scientific competencies, this factor, elucidated by nurses working in the $\mathrm{NICU}^{(2)}$.

These data reinforce that the demand for training is due to several factors, which are linked to the individual desire for moments of lifelong learning. Thus, the perception of dissatisfaction with skills and competences is seen as a condition that arouses greater interest and favors the opening for new knowledge; therefore, on the other hand, recognizing yourself as a self-sufficient professional minimizes the chances of looking for educational actions $^{(2,24-25)}$.

The way nurses work and develop their profession is linked to the environment in which they are inserted - their limitations, their restrictions and organizational requirements. It is evident, in this study, that nurses experience little investment and participation from the organizations in which they work. Such reality is unfavorable to the continuity of training, since the literature shows institutional involvement as a stimulant for the search for educational activities ${ }^{(2,7)}$.

Thus, the values, cultural context and beliefs embedded in a unit can directly influence the search for improvement or not, increasing or, conversely, decreasing professional expectations. It is clear that interprofessional support and collaboration impels the individual to commit to learning or to abandon $i^{(2,7,26)}$.

It is articulated that the continued training inserts the professionals in the discussions about health practices, with improvement of their work process, as well as bringing team members closer in a participatory way. They must be a strategic part of organizational change. For this, it is necessary to raise institutional awareness and valorization on this theme, since behavioral, attitudinal and progressive transformations can happen institutionally, collectively and individually ${ }^{(2,16,25)}$.

It is essential to promote sufficient motivation to health professionals in order to stimulate the development of the ability to adopt behavior that changes in favor of human beings and that seeks alternatives so that the care practiced is broader than that seen in theory. The motivation for this must be given by the health institutions, direct coordinators and the caregiver, being important to maintain and strengthen this partnership ${ }^{(2,27-28)}$.

\section{Study limitations}

The territorial approach used to obtain participants allows revelations about a particular context, which can be taken as limiting. However, the study has the potential to empower the elements that need to be considered in government interventions, with a view to transforming locoregional situations in terms of disparities in the quality of the care and training opportunities ${ }^{(2)}$.

\section{Contributions to the field of Nursing}

The study brought contributions and reflections about the care in neonatal intensive care and the professional training of nurses who experience their practice in this environment, reinforcing the importance of understanding their focus of action and attention, as well as stimulating, institutionally, the engagement in training actions and that are foundations for the growth of this professional. Thus, it will allow the identification of elements for changes in terms of the development of continuing education and for maintaining the qualification of care as a horizon for health practices - in the case of this study, in NICU, but liable to be transposed to other scenarios ${ }^{(2)}$.

\section{FINAL CONSIDERATIONS}

The motivation expressed by the NICU nurse for the search for training is present through movements marked by the limitations apprehended in practice about the care for risky new-borns, that is, this professional envisions the acquisition of knowledge necessary to work with quality in such a specific health scenario(2).

Based on these issues, the evidence presented here reinforces the need for investment in professional nurses. Such investment must consider its potential, its knowledge, its aspirations, its individuality. In addition, it must consolidate actions based on health education as they constantly reinforce the professional commitment to the real conception of quality of care, involving the uniqueness of each context from a humanizing and integral perspective $^{(2)}$.

\section{FUNDING}

This study was financed in part by the Coordenação de Aperfeiçoamento de Pessoal de Nível Superior - Brasil (CAPES) - Finance Code 001 


\section{REFERENCES}

1. World Health Organization (WHO). World health statistics annual: 2018 [Internet]. Geneva;2018 [cited 2018 Jun 5]. Available from: http:// www.who.int/mediacentre/factsheets/fs282/en/

2. Basso de Oliveira Al. Enfermeiro de Unidade de Terapia Intensiva Neonatal: motivação para a formação profissional [Dissertação]. 2018. Universidade Federal de São Carlos - UFSCar, São Carlos;118 f.

3. Als $\mathrm{H}$, (Editor). Cuidados de desenvolvimento individualizados para bebês prematuros: prematuridade. 8th ed. Boston: Enciclopédia sobre o desenvolvimento da primeira infância;2017. 7 p. 4 vol.

4. Milette I, Martel MJ, Silva MR, Mcneil MC. Guidelines for the institutional implementation of developmental neuroprotective care in the NICU: Parte B: Recommendations and Justification. a joint position statement from the CANN, CAPWHN, NANN, and COINN. Can J Nurs Res. 2017;49(2):63-74. doi: 10.1177/0844562117708126

5. Sá ACMG, Ferreira ERO, Xavier JC, Alves CM. Contribuições da Educação Permanente para Qualificação da Assistência de Enfermagem em um Hospital Público. Rev Bras Ciên Saúde. 2018;22(1):87-94. doi: 10.4034/rbcs.2018.22.01.12.

6. Fang W. Relationships between optimism, educational environment, career adaptability and career motivation in nursing undergraduates: a cross-sectional study. Nurse Educ Today. 2018;68:33-9. doi: 10.1016/j.nedt.2018.05.025

7. Kinsella D, Fry M, Zecchin A. Motivational factors influencing nurses to undertake postgraduate hospital-based education. Nurse Educ Pract. 2018;31:54-60. doi: 10.1016/j.nepr.2018.04.011

8. Xin Z, Shih-Yu L, Jingli C, Huaping L. Factors influencing implementation of developmental care among NICU Nurses in China. Clin Nurs Res. 2016;25:238-253. doi: 10.1177/1054773814547229

9. Appel-Silva M, Welter GW, Argimon IL. A teoria da autodeterminação e as influências socioculturais sobre a identidade. Psicol Rev [Internet]. 2010 [cited 2018 Nov 5];16(2):351-369. Available from: http://pepsic.bvsalud.org/pdf/per/v16n2/v16n2a08.pdf.

10. Clandinin DJ, Connelly FM. Narrative inquiry: experience and story in qualitative research. São Francisco: Jossey-Bass; 2004.240 p.

11. Lieblich A, Tuval-Mashiach R, Zilber T. Narrative research: reading analysis and interpretation. Thousand Oaks: CA: Sage; 1998.

12. Vinuto J. A amostragem em bola de neve na pesquisa qualitativa: um debate em aberto. Temáticas. 2014;22(44):203-20. doi: 10.20396/ tematicas.v22i44.10977

13. Fundação Seade. Anuário estatístico do Brasil: 2018 [Internet]. São Paulo; 2018 [cited 2018 Sep 9]. Available from: https://biblioteca.ibge. gov.br/biblioteca-catalogo?id=720\&view=detalhes

14. Banco de dados do sistema único de saúde. Informações de saúde, indicadores de saúde: nascidos vivos $1994-2012$ [Internet]. 2012 [cited 2018 Apr 10]. Available from: http:www.datasus.gov.br

15. Fontanella BJB, Luchesi BM, Saidel MGB, Ricas J, Turato ER, Melo DG. Amostragem em pesquisas qualitativas: proposta de procedimentos para constatar saturação teórica. Cad Saúde Pública. 2011;27:388-94. doi: 10.1590/s0102-311x2011000200020

16. Flores GE, Oliveira DLL, Zocche DAA. Educação permanente no contexto hospitalar: a experiência que ressignifica o cuidado em enfermagem. Trabalho Educ Saúde. 2016;14(2):487-504. doi: 10.1590/1981-7746-sip00118

17. Leite TMC, Vergílio MSTG, Silva EM. Processo de trabalho do enfermeiro pediatra: uma realidade a ser transformada. Rev Rene. 2017;18(1):2634. doi: 10.15253/2175-6783.2017000100005

18. Lage CEB, Alves MS. (Des) valorização da Enfermagem: implicações no cotidiano do Enfermeiro. Enferm Foco [Internet]. 2016 [cited 2018 Sep 9];7(3/4):12-16. Available from: http://revista.cofen.gov.br/index.php/enfermagem/article/view/908/338

19. Lara MO, et al. Percepção da equipe de enfermagem quanto à assistência provida em uma unidade de internação. Rev Bras Ciên Saúde [Internet]. 2018 [cited 2018 Sep 9];22(3):195-202. doi: 10.4034/rbcs.2018.22.03.02

20. Hoeve YT, Kunnen S, Brouwer J, Roodbol PF. The voice of nurses: Novice nurses' first experiences in a clinical setting. A longitudinal diary study. Journal Of Clinical Nursing [Internet]. 2018 [cited 2018 Sep 5];27(7/8):1612-1626. doi: 10.1111/jocn.14307

21. Püschel VAA, Costa D, Reis PP, Oliveira LB, Carbogim FC. O enfermeiro no mercado de trabalho: inserção, competências e habilidades. Rev Bras Enferm. 2017;70(6):1220-6. doi: 10.1590/0034-7167-2016-0061

22. Tavares APC, Leite BS, Silveira IA, Santos TD, Brito WAP, Camacho ACLF. Análise das publicações nacionais sobre educação a distância em enfermagem: revisão integrativa. Rev Bras Enferm. 2018;71(1):214-22. doi: 10.1590/0034-7167-2016-0454

23. Azevedo IC, Silva GWS, Vale LD, Santos QG, Cassiano NA, Morais EF, et al. Educação continuada em enfermagem no âmbito da educação permanente em saúde: revisão integrativa de literatura. Saúde Pesqui. 2015;8(1):131-40. doi: 10.17765/1983-1870.2015v8n1p131-140

24. Winters JRF, Prado ML, Waterkemper R, Kempfer SS. Formação dialógica e participativa na enfermagem: Contribuição ao desenvolvimento do pensamento crítico-reflexivo e criativo de acadêmicos. Rev Mineira Enferm. 2017;21(1):1-7. doi: 10.5935/1415-2762.20170077

25. Costa MAR, Souza VS, Teston EF, Spigolon DN, Matsuda LM. Educação Permanente em saúde: a concepção freireana como subsídio à gestão do cuidado. Rev Pesqui: Cuid Fundam. 2018;10(2):558-564. doi: 10.9789/2175-5361.2018.v10i2.558-564 
26. Yarbrough S. Professional values, job satisfaction, career development, and intent to stay. Nurs Ethics. 2016;24(6):675-85. doi: $10.1177 / 0969733015623098$

27. Brekelmans G. Factors influencing nurse participation in continuing professional development activities: Survey results from the Netherlands. Nurse Educ Today. 2016;40:13-19. doi: 10.1016/j.nedt.2016.01.028

28. Campos KFC, Sena RR, Silva KL. Educação Permanente nos serviços de saúde. Esc Anna Nery. 2017;21 (4):1-10. doi: 10.1590/2177-9465-ean-2016-0317 